\title{
Kerkvorming en -ontwikkeling in die Nuwe-Testamentiese tydvak
}

\author{
G M M Pelser \\ Departement Nuwe-Testamentiese Wetenskap \\ Universiteit van Pretoria
}

\begin{abstract}
The origin and development of the church in the New Testament era

This study considers the question as to how the church originated, in view of the fact that it was not founded or intended by Jesus, and examines how it developed during the course of time covered by the writings of the New Testament. It concludes firstly that the church did not originate as a single entity, but as different believing communities following the death of Jesus, secondly that the delay of the parousia resulted in the institutionalizing of the church and consequently, in the loss of what can be regarded as some of the basic and most important characteristics of the church, especially as far as Paul's understanding is concerned. The study concludes with a list of what could be regarded as common features of the church as portrayed by most of the documents of the New Testament.
\end{abstract}

\section{INLEIDING}

Die oogmerk van hierdie studie is om as onderdeel van die oorkoepelende tema Die Hervormde Kerk, kerkbegrip en kerkvorming te probeer nagaan wat uit die dokumente van die Nuwe Testament afgelei kan word in verband met die ontstaan, die denke oor en die ontwikkeling van die "kerk" in die Nuwe-Testamentiese tydvak. Dit is met goeie rede en behoef geen argumentvoering nie dat wanneer daar ook al oor die wese, funksie en opdrag van die kerk besin is, dit in hoofsaak die Nuwe Testament is wat vir hierdie doel geraadpleeg is, en dieselfde sal geld van enige sodanige vraagstelling vir vandag en môre. 
Maar dan moet ook steeds in gedagte gehou word dat die begrip "kerk" soos dit in die geskiedenis van die kerk se denke en praktyk in verband met die kerk ontwikkel het, in verskeie opsigte nie gelyk te stel is met die selfverstaan wat die vroegste geloofsgemeenskappe oor hulleself gehad het nie. Schmithals (1994:155) is daarom gelyk te gee wanneer hy sê: "Im Rahmen der frühchristlichen Theologiegeschichte von 'Kirche' und von kirchlichen 'Ämtern' zu sprechen, ist in gewisser Weise ein Anachronismus". Alles pleit ook vir die korrektheid van sy opmerking dat wat die kerkbegrip betref, die vroegste Christelike gemeenskappe nóg vir hulle sterk divergerende gemeenskapsvorme 'n eenheidsbenaming sou besit het, nóg van buite hulle geledere as 'n geïntegreerde sosiale grootheid waargeneem en dienooreenkomstig aangedui sou gewees het (Schmithals 1994:155; kyk ook Mack 1995:45). Maar afgesien van die gevaar van anachronisme is daar ook die feit van die veelheid van persepsies oor die "kerk" wat daar by die verskillende geloofsgemeenskappe of outeurs van die Nuwe Testament bestaan het, tot so 'n mate dat "veelheid" as die oorheersende tipering van die Nuwe-Testamentiese voorstellings oor die kerk beskou kan word (so tereg Grappe 2001:1000). Ons kan daarom nie van dié ekklesiologie van die Nuwe Testament praat nie maar hoogstens van 'n verskeidenheid van ekklesiologiese tipes of modelle. "Das Neue Testament schenkt uns keine ecclesiologia perennis, bietet uns jedoch ekklesiologische Grundtypen" (Käsemann 1964:262).

Dit is om hierdie rede te verstane dat die pogings in die geskiedenis van die kerk om uit die Nuwe Testament iets oor die kerk af te lees of af te lei, só divers was dat dit verskillende kerkbegrippe of -modelle en daarom verskillende Christelike groeperings en denominasies ten gevolg gehad het. Dit blyk verder dat die diversiteit aan kerklike modelle wat in die kerkgeskiedenis uit die Nuwe Testament na vore gebring is, rofweg in drie groepe uiteenval. Daar is dié waarby 'n bepaalde model, byvoorbeeld die herderkudde-model, die oorwegende is. Dan is daar dié waarin bepaalde elemente van verskillende modelle met mekaar gekombineer is, en laastens dié waarin verskillende modelle, byvoorbeeld die herder-kudde- en die liggaam- model, eenvoudig met mekaar gekombineer is, of hulle in essensie met mekaar harmoniseerbaar is of nie.

In wat hieronder volg, gaan ek nie probeer om in besonderhede, asof enigsins moontlik, die ontstaan en ontwikkeling van die kerkbegrip in die Nuwe Testament na te 
gaan nie. Ek gaan net in breë trekke die redelik identifiseerbare en prominentste "kenmerke" probeer aandui. In 'n vorige artikel (Pelser 1995; kyk ook Roloff 1993) het ek reeds een en ander probeer sê oor hoe die verskillende outeurs van die Nuwe Testament, of dan die geloofsgemeenskappe wat daarin verteenwoordig is, oor die kerk gedink het en die bedoeling is nie om dit, behalwe waar nodig, hier te herhaal nie.

\section{DIE ONTSTAAN VAN DIE KERK}

Dit is bykans deurgaans die geval dat wanneer daar in min of meer omvattende sin oor die kerk in die Nuwe Testament gehandel word, begin word met die vraag na die ontstaan van die kerk. Hoewel hierdie studie nie bedoel is om omvattend te wees nie, ag ek dit tog nodig dat die vraag na die ontstaan van die kerk ook hier ter sprake gebring moet word. Die rede vir hierdie vraagstelling is natuurlik dat as ons duidelikheid kan kry oor die redes vir die ontstaan van die kerk dit kan meehelp tot 'n beter verstaan van wat die kerk is en behoort te wees.

Ten spyte van die feit dat daar in artikel 27 van die Nederlandse Geloofsbelydenis verklaar word dat die kerk daar was "van die begin van die wêreld af", kan 'n mens in terme van wat normaalweg onder die begrip kerk verstaan word, kwalik anders oordeel as dat die "Jesusgebeure" fundamenteel as die terminus a quo van die ontstaan van die kerk gesien moet word. Maar nou moet hierby ook weer daarop gewys word dat om te sê die "Jesusgebeure", te vaag en te algemeen is om as 'n bevredigende antwoord te kan geld. Om hierdie rede sal daar onvermydelik gevra moet word wat van hierdie gebeure in die besonder die ontstaan van die kerk ten gevolg gehad het en in watter mate dit bepalend was vir die wese van die kerk. Om egter in besonderhede op hierdie vraag te moet antwoord, stel 'n mens voor 'n probleem, aangesien dit nie so duidelik is wie of wat werklik die spoorslag gelewer het vir die ontstaan van die kerk nie.

Daar blyk vandag konsensus daaroor te wees dat Jesus nie die kerk gestig of in die vooruitsig gestel het nie, ten minste nie die kerk soos dit met 'n organisatoriese en ampstruktuur na vore gekom het nie (kyk o a Bultmann 1968:9; Conzelmann 1968:49; Roloff 1978:510; Schmithals 1994:23,156; Von Lips 1996:60; Funk 1996:311; Grappe 2001:1000; Pelser 1994:312). Hoewel daar oor hierdie aspek konsensus is, word daar nogtans deur sommige die oortuiging gehuldig dat Jesus wel op een of ander wyse met 
die ontstaan van die kerk verbind kan word, al is dit dan ook op indirekte wyse. Om maar net 'n paar te noem, vind ons argumente soos dat die woorde en optrede van Jesus die vooronderstelling (Conzelmann 1968:49) vir die ontstaan van die kerk was of dat daar in sy woorde en optrede 'n implisiete ekklesiologie (Trilling 1988:82) opgesluit gelê het, byvoorbeeld in sy uitnodiging aan mense om bepaalde gevolgtrekkings uit sy koninkrykverkondiging te maak (Grappe 2001:1001) of dat die kiesing van die "twaalftal" daarop dui dat Hy die totstandkoming van 'n nuwe Godsvolk in die vooruitsig gestel het (Kirchschläger 1990:26; Von Lips 1996:61).

Hoewel dit op die oog af anneemlik klink, is hierdie aannames nie so vanselfsprekend nie. Terwyl daar naamlik konsensus daaroor is dat die sentrale komponent van Jesus se verkondiging die koningsheerskappy van God was, is nie almal daarvan oortuig dat sy hoorders of volgelinge verstaan het wat Hy daarmee bedoel het nie. Mack gee miskien die beste uitdrukking aan hierdie twyfel wanneer hy sê:

$[\mathrm{T}]$ he different views and practices that developed are evidence for the fact that Jesus did not provide a program for starting a new religion. If he did, his followers did not understand what it was. The many views they came up with, both about what the kingdom should be and about what Jesus must have been, tell against a clear and common conception of the kingdom.

(Mack 1995:45; vgl egter Theißen 1999:40)

Wat ons ook al sou wou veronderstel in verband met die historiese Jesus en die ontstaan van die kerk, die feit blyk te wees dat eers die Paasbelydenis en nie die aardse Jesus nie, beskou kan word as voldoende vooronderstelling vir die ontstaan van die kerk (so tereg Schmithals 1994:21). Verder word daar in toenemende mate betwyfel dat die twaalftal 'n voor-Pase groep of instelling was, dit wil sê dat hulle inderdaad deur die historiese Jesus met 'n bepaalde doel voor oë geroep of aangestel is (so o a reeds Bultmann 1968:40; kyk verder Schmithals 1994:175; Roloff 1996: 142; kyk egter ook Von Lips 1996:61; Theißen \& Merz 1997: 201). Die jongste voorbeeld hiervan is die Jesus Seminar wat, hoewel daar nie eenstemmigheid bereik kon word oor die vraag of Jesus inderdaad mense tot dissipels geroep het nie, wel met verwysing na Markus 3:13-19 eenparig tot die 
slotsom gekom het dat "the number 'twelve' in connection with an inner circle of disciples" 'n fiksie is (Funk 1998:71). Hierby moet daarop gewys word dat daar geen aanduiding is dat hierdie twaalftal enige beduidende leiersrol in die Jesusbeweging gespeel het nie. "Ein Kirchenleitungsgremium im eigentlichen Sinn dürften sie niemals gewesen sein" (so tereg Roloff 1996:143).

Dit bring ons terug by die vraag na wat dan wel gedien het as die stimulus vir die ontstaan van die kerk en wat ons daaruit met betrekking tot die aard van die kerk kan aflei. As ons in hierdie verband in die eerste plek na 'n "ontstaansdatum" sou vra, sal die meeste Bybellesers waarskynlik dink aan die beskrywing wat in Handelinge van die sogenaamde Pinkstergebeure gegee word, en daar is min twyfel dat die outeur van Handelinge sy leser(s) dit so wou laat verstaan. Hierteenoor gee Matteus (28:16-20) en Johannes (20:19-23) hulle lesers die indruk dat dit alles met die Paaservaring(s) van een of meer van die Jesusvolgelinge begin het en dit wil voorkom of die meerderheid navorsers laasgenoemde as die waarskynlikste aanvaar (kyk Von Lips 1996:61). Hoewel Markus eindig met die antiklimaks van die vroue wat nie die opdrag van die jongman (16:7) aan die dissipels gaan oordra nie (16:8), veronderstel die belofte dat die opgestane Jesus in Galilea aan sy dissipels gaan verskyn (kyk ook Mk 14:28), minstens dat ook Markus die Paaservaring van die vroue gesien het as die begin van 'n nuwe bedeling vir die Jesusvolgelinge, of dan 'n nuwe beweging waarby hulle betrokke sou wees. Dit lyk dus asof ook Markus die Paasgebeure gesien het as die eintlike ontstaansdatum van die kerk.

Ten spyte van hierdie verskil in "datering" moet daar egter op gewys word dat die Paasgebeure natuurlik ook deur die outeur van Lukas-Handelinge gesien is as van grondliggende betekenis vir die ontstaan van die kerk (kyk Hand 2:29-36; en ook Luk 24:44-49). Verder blyk daar, met die uitsondering van Markus, 'n opvallende en belangrike ooreenkoms tussen bogenoemde berigte te wees en dit is dat berig word dat die Jesusvolgelinge in al hierdie gevalle met die Gees toegerus is en die opdrag tot verkondiging ontvang het. Dit blyk dus dat die geloofsgemeenskappe wat deur hierdie dokumente verteenwoordig is van oortuiging was dat die "kerk" bestaan het uit mense wat, toegerus met die Heilige Gees, in die eerste plek die opdrag gehad het om die Paasgebeure te verkondig. Op sterkte hiervan kan 'n mens dus sê dat die verkondiging 
van die Paaskerugma in hierdie kringe gesien is as die totstandkoming van die kerk. Streng gesproke het nie die Paasgebeure as sodanig dus die totstandkoming van die kerk ten gevolg gehad nie, maar wel 'n bepaalde interpretasie van die Paasgebeure (so tereg Schmithals 1994:25). En in hierdie verband moet daarop gewys word dat die interpretasie van die Paasgebeure in die evangelies en Handelinge beslis nie dieselfde is as wat Paulus daarvan gemaak het nie. Met die uitsondering van wat waarskynlik uit Markus 10:45 af te lei is, word Jesus se dood in eersgenoemde dokumente hoegenaamd nie so sentraal in versoenende of plaasbekledende sin verstaan as by Paulus nie. Dit word eerder verstaan in die sin van die onskuldige lyding en gevolglike verhoging van 'n regverdige, 'n motief wat in sowel die Ou Testament (Psalms) as die Jodedom alom bekend was (kyk Schweizer 1962:21-33; 53-62). Hoewel daar ook geglo is dat die onskuldige lyding en dood van 'n regverdige versoenende betekenis vir ander kon hê, blyk die klem hier eerder op Jesus se verhoging as op sy dood gelê te gewees het. "Das Bild vom leidenden und erhöhten Gerechten hat also auch die vor- und nebenpaulinische Christusanschauung der Gemeinde bestimmt" (Schweizer 1962:61).

Dit is bekend dat daar in die jongste tye veral met die bestudering van die Q-bron en die Thomasevangelie sowel as deur die navorsing oor die historiese Jesus die oortuiging na vore gekom het dat die Paasgebeure nie by alle vroeë Jesusvolgelinge dieselfde uitwerking gehad het nie. So maak die Thomasevangelie geen melding van die dood en opstanding van Jesus nie en daar is geen aanduiding dat Q dit beskou het as deel van die Christelike boodskap nie. "The Gospel of Thomas and $Q$ challenge the assumption that the early church was unanimous in making Jesus' death and resurrection the fulcrum of Christian faith" (Koester 1990:86). Mack, onder andere, skryf dit daaraan toe dat die eerste Jesusbewegings Jesus gesien het as 'n "founder-teacher of a school of thought" (Mack 1995:46) en dat sy dood dus nie by hulle die rol gespeel het wat dit later gespeel het in die Christus-kultus wat rondom Hom ontwikkel het nie (Mack 1995:7576). Dit beteken dat as ons die term "kerk" vir hierdie mense moes gebruik, ons sou moes dink aan 'n kerk sonder kruis en opstanding. Hiervolgens is die verkondiging van die dood en opstanding van Jesus as verlossingsgebeure dus nie verteenwoordigend van die eerste Jesusbeweging(s) nie, maar is dit 'n interpretasie van die dood van Jesus wat eers later na vore getree het. 
Hieruit volg dat daar met betrekking tot die vraag na die ontstaan van die kerk in die vroegste Christendom met hoofsaaklik twee tradisies rekening gehou moet word, naamlik die tradisie oor die "woorde van Jesus" en dié oor sy "dood en opstanding", deur Crossan ook na verwys as onderskeidelik die "Life Tradition" en die "Death Tradition" (Crossan 1998:415). Dit is bekend dat laasgenoemde tradisie, wat veral as die "kerugmatiese" tradisie of die tradisie van die "Paaskerugma" bekend geword het, die oorheersende in die kerk geword het. Hierdie oorheersing word egter in die jongste tyd deur verskeie geleerdes, veral historiese-Jesus navorsers, as onaanvaarbaar geag. En terwyl sommige (Kloppenberg 1987:22; Crossan 1998:408, 415) oordeel dat aan die een tradiese nie voorrang bo die ander gegee mag word nie, is daar ander wat sover gaan as om die Paaskerugma as onversoenbaar met die historiese Jesus se optrede en intensies te beskou (Mack 1995:47, 75-76; Funk 1996:312-313). Wat opvallend is wanneer 'n mens na die evangelies en Handelinge kyk, is dat ons hier in werklikheid 'n kombinasie van die twee tradisies aantref, al kom die dood-en-opstanding-tradisie soos dit in hierdie dokumente voorkom, nie heeltemal ooreen met wat dit by Paulus geword het nie.

Dit lê voor die hand dat die "kerklike" selfverstaan wat uit hierdie onderskeie tradisies sou voortgespruit het, radikaal van mekaar sou verskil. In die een geval sou kerkwees klaarblyklik gesien gewees het as 'n lewe in ooreenstemming met die woorde van Jesus of dan 'n lewe in gehoorsaamheid aan die wil van God soos Jesus dit geïnterpreteer het. Dit sou dus gesien gewees het as 'n lewe in onderworpenheid aan die koningsheerskappy van God, 'n lewe in die regte verhouding met God, beheers deur die genade van God en die liefde van en vir God. Hoewel dit nie ervaar sou gewees het as 'n toekomslose lewe nie, sou dit primêr ervaar gewees het as 'n lewe wat 'n mens hiér en nóú laat deel in die onmiddellike verhouding met God en daarom in die lewe self en in die onmiddellikheid van hierdie lewe. In die ander geval sou kerkwees gesien gewees het as 'n lewe op die wyse waarop ons, merendeels as resultaat van die Pauliniese verstaan van die Paaskerugma, gewoond geraak het om daaroor te dink. In hierdie geval sien gelowiges hulleself as mense wat deur die dood en opstanding van Jesus vir hulle, verlos is van sonde en dood deurdat hulle saam met Hom hulle ou, sondige bestaanswyse afgesterf het en deel gekry het aan 'n nuwe lewe "in Christus" wat hulle uit dankbaarheid en in gehoorsaamheid aan God moet lewe. Maar hierdie lewe hoe nuut en vol ook al, is 
nog nie die ideale en finale nie maar in 'n sekere sin voorlopig en onvolledig in afwagting van en uitsien na die ware en ewige lewe wat op 'n bepaalde tydstip, by die wederkoms van Christus, sal realiseer. Soos ons weet, is aan hierdie kerklike selfverstaan ook ten nouste gekoppel die verwagting van die toekomstige omkering van lotgevalle, van tweërlei vergelding, naamlik hemelse beloning vir dié wat gedurende hulle aardse lewe goed gedoen of gely het; straf vir dié wat 'n sondige en lekker lewe gely het.

Moet of kan hierdie twee persepsies oor gelowig- of kerk-wees op gelyke voet naas mekaar gehandhaaf word? Kan albei as 'n legitieme interpretasie van die Jesusgebeure aanvaar word? Die antwoord hierop hang af van wat 'n mens as kriterium vir jou oordeel stel. Hierbo het ons gesien dat iemand soos Mack wat vír die "Jesuswoorde" tradisie met afwysing van die ander tradisie kies, dit doen omdat hy oordeel dat dit 'n legitieme verstaan van die historiese Jesus en sy woorde verteenwoordig en buitendien die oorspronklike tradisie is. Wat ' $n$ antwoord op hierdie vraag uiters moeilik maak, is die probleem dat ons nie weet hoe Jesus self oor sy dood gedink het nie, wat sonder twyfel die moeilikste vraag is om in verband met die historiese Jesus te beantwoord. Uitsprake soos in Markus 8:31 par en 10:45 word in die kritieswetenskaplike kader lank reeds nie meer as Jesuswoorde nie, maar as gemeenteteologie beskou. En al sou 'n mens ook wou aanvaar dat Jesus moet voorsien het dat Hy in botsing met die owerhede sou kom en sy lewe as gevolg daarvan sou verloor, weet ons nog nie of Hy sou geoordeel het dat sy dood van versoenende betekenis vir sy volgelinge sou wees nie. Gesien in die lig van die hierbo genoemde Joodse tradisie oor die lydende regverdige, iets wat veral in die Makkabeërstryd sterk na vore gekom het, hoef dit natuurlik nie as onmoontlik geag te word dat Jesus wel so oor sy dood kon gedink het nie. Meer as dit kan egter nie gesê word nie en 'n oortuigende antwoord bly 'n mens ontwyk. Aan die ander kant is dit heeltemal denkbaar dat die "dood en opstanding" tradisie teen die agtergrond van die tradisie van die lydende regverdige kon ontstaan het, terwyl ook die rol wat Jesaja 53 gespeel het, eksplisiet ter sprake is. Maar ook ten opsigte van hierdie moontlike agtergrond of aanleiding sal 'n definitiewe antwoord ons bly ontwyk. Waarom 'n deel van die vroeë Jesusbeweging só oor sy dood begin dink het terwyl ander dit nie gedoen het nie, is ewe moeilik om te verklaar. Om dit aan 'n poging tot oorkoming van kognitiewe dissonansie toe te skryf (so o a Theißen 1999:44-47) lyk na 'n 
baie aantreklike verklaring, maar moet in terme van die doeleindes van hierdie studie daar gelaat word.

Om terug te kom op die vrae hierbo, dit blyk dat ons in terme van wat deur middel van die historiese Jesus navorsing na vore gekom het, onvermydelik sal moet oordeel dat net die eerste tradisie gevolg gegee het aan die visie en intensie van die historiese Jesus. Dit impliseer dat, gesien vanuit die oogpunt van die historiese Jesus, die tweede tradisie nie as legitieme interpretasie van die Jesusgebeure beskou kan word nie. Om so te oordeel, beteken egter nie dat die tweede tradisie by die deur uitgevee moet word nie. Dit het klaarblyklik reeds betreklik vroeg vir 'n beduidende deel van die Jesusbeweging goeie sin gemaak en die oorheersende in die kerk geword. Maar terwyl die gedagte dat iemand sy of haar lewe vir ander selfs tot in die dood feil kan hê, volkome met die persoon van Jesus gerym sou kon word, het dit wat uiteindelik in die teologiegeskiedenis van die "dood en opstanding" tradisie gemaak is, in verskeie opsigte 'n karikatuur van hierdie tradisie gemaak. 'n Mens dink in hierdie verband veral aan die Anselmiaanse genoegdoeningsleer wat so 'n prominente plek in die kerk se soteriologiese denke ingeneem het.

Ten slotte moet daarop gewys word dat die kerk nie oornag ontstaan het nie, veral nie as 'n afsonderlike beweging bestaande uit Jode én nie-Jode nie. Soos al dikwels deur navorsers uitgewys is, dui alles daarop dat minstens die Joodse deel van die vroegste Jesusbeweging nog vir etlike dekades binne die Joodse gemeenskap bestaan en geopereer het. Volgens Theißen (1999:164-165) is dit eers na 'n ongeslaagde poging, wat verskillende stadia deurloop het, om Judaïsme te universaliseer en sodoende vir alle nieJode toeganklik te maak dat die kerk gedurende die laaste kwart van die eerste eeu tot stand gekom het. "So we can say that the origin of primitive Christianity is the history of a failed attempt to universalize Judaism. The creative force of primitive Christianity showed itself in the transformation of this failure into motives for founding an independent religion" (Theißen 1999:165). Dit is duidelik dat dit vir Theißen gaan oor die vraag van wanneer af daar met die Christendom as 'n afsonderlike en volledig selfstandige godsdiens los van die Joodse godsdiens rekening gehou kon word. Hierin staan hy nie alleen nie en hoef daar nie van hom verskil te word nie. Wat egter nie ontken kan word nie, is dat minstens wat die Pauliniese gemeentes betref, 'n mens nie die 
indruk kry dat hier nog nie sprake was van 'n eie identiteit en karakter nie. Maar of 'n mens nou met Theißen se weergawe van die saak saamstem of nie, daar kan nie twyfel daaroor bestaan dat kerkvorming eerder by wyse van 'n proses as momenteel plaasgevind het, terwyl ook in gedagte gehou moet word dat sake nie in alle streke eners verloop het nie.

\section{VROEË KERKLIKE GROEPVORMINGS EN ONTWIKKE- LINGS}

Hierbo is reeds gewys op die kerklike verskeidenheid wat daar in die onderskeie dokumente van die Nuwe Testament weerspieël word en na die aandag wat reeds in publikasies daaraan gegee is. Wat hierdie verskeidenheid betref, is een saak egter duidelik en dit is dat soos die ontstaan van die kerk 'n proses was, so was die verskeidenheid nie gewoon van die begin af aanwesig nie, maar iets wat hoofsaaklik vanweë twee faktore ontwikkel het. Die eerste is die meningsverskil en konflik wat daar as gevolg van verskillende interpretasies van die Jesusgebeure ontstaan het, terwyl die tweede die situasie was wat as gevolg van die uitbly van die naby verwagte paroesie ontstaan het.

Dit blyk dat 'n faktor wat betreklik vroeg tot meningsverskil en afsplintering of groepvorming gelei het, die kwessie van die insluiting van nie-Jode in die aanvanklik uitsluitlik Joodse beweging was. Soos bekend, getuig nie alleen Handelinge op verskeie plekke hiervan nie, maar ook Paulus. Ongelukkig het die outeur van Handelinge die sluier te effens gelig oor die omvang en aard van hierdie meningsverskille, veral wat die situasie in verband met die "sewe" in Handelinge 6 betref. Hy het klaarblyklik, omdat hy klem wou lê op kerkleiding alleen deur die Gees maar die meningsverskille ook nie heeltemal kon verswyg nie, die verskille in 'n ansienlike mate verbloem. Hy het hierdeur die realiteit in die agtergrond gedring omdat hy dit as bedreiging vir sy grondliggende teologiese aksioma, die leiding deur die Gees, beskou het (Roloff 1996:138). Nietemin kan die kwessie oor watter Joodse gebruike en identiteitsmerkers, soos die besnydenis, in die geval van nie-Joodse gelowiges agterweë gelaat kon word, gesien word as die begin van die beweging waarby Paulus aansluiting sou vind en wat die grondslag gelê het vir wat by hom bekend geword het as die wetsvrye evangelie (vgl 
Theißen 1999:164). So kan die konflik wat reeds in die eerste generasie tussen die Hebrë̈rs en die Helleniste ontstaan het, gesien word as die begin van die pluraliteit wat in die tweede en derde generasie verder sou toeneem en uiteindelik behalwe vir die hoofstrome van Joodse, Sinoptiese (met variasies), Pauliniese en Johannese kerke, ook nog die kleinere verdelings soos die Deutero-Pauliniese, Apokaliptiese en ander sou oplewer (kyk weer Roloff 1993; Pelser 1995; Von Lips 1996; en veral Theißen 1999:252261). Terwyl hierdie pluraliteit voor die hand liggend en betreklik maklik in die onderskeie dokumente identifiseerbaar is, bly die groot probleem in verband hiermee dat daar eenvoudig te min inligting beskikbaar is om uit te maak wat in elkeen van die gevalle werklik aanleiding gegee het tot die verskil in denke en die gevolglike groepvorming.

Soos hierbo aangedui, moet die uitbly van die paroesie gesien word as die tweede beslissende faktor in die verandering van denke en gevolglike pluralisering van die vroegste Christendom. Hoewel nie alle groeperings eners hierop gereageer het nie, is dit duidelik dat die besef dat die kerk homself in die wêreld moes vestig en nog vir 'n onbepaalde tyd in die geskiedenis sou voortbestaan en deel van die geskiedenis sou wees, gelei het tot 'n veranderde selfverstaan. Hierdie veranderde selfverstaan het op verskillende wyses gemanifesteer, veral wat betref die beskouing oor die aard en rol van die kerk asmede die struktuur en rol van die ampte. Wat die deutero-Pauliniese omgewing betref, vind ons onder andere dat die kerk nie meer primêr die plaaslike gemeente is nie maar tot ' $n$ kosmiese grootheid geword het wat op bykans gnostiese wyse met Christus as die hoof verbind is en vanwaaruit Christus heerskappy oor die wêreld en veral die kosmiese magte voer (Kolossense); dat die kerk bestaande uit Jode én nie-Jode die openbaring van die Goddelike misterie en 'n hemelse, bykans Goddelike entiteit is en in so 'n mate self heilmiddel geword het dat ekklesiologie die vooronderstelling vir soteriologie geword het (Efesiërs); dat die tradisie en die bewaring van die tradisie as kenmerk van kerkwees in so 'n mate domineer dat die Gees aan die tradisie ondergeskik gemaak word en dat soveel prominensie aan die amp verleen word dat die Gees in werklikheid nog net as amps-Gees 'n funksie te vervul het, terwyl Christen-wees basies neerkom op Christelike burgerskap (Pastorale Briewe). 
Ons het hier te make met 'n ontwikkeling in die vroeë kerk waarna meermale en in toenemende mate verwys is as vroegkatolisisme (kyk o a Küng 1970; Schulz 1976; Hahn 1986; Pelser 1990; Engelbrecht 1995) en waarin daar bepaalde opvattings oor die kerk na vore getree het wat volgens alle aanduidings nie vroeër, minstens nie by Paulus, die geval was nie. Luz (1974:90-92) het deur middel van die volgende tipologiese kenmerke ' $n$ besonder raak beskywing van die vroegkatolieke ontwikkeling in die vroeë kerk gegee: a. Die bewuste teruggryping op die apostoliese tyd en die bewaring van die apostoliese tradisie, maar sonder dat werklik daarin geslaag is om aan die apostoliese getrou te bly. "Denn das was etwa für Paulus und seine Gemeinden das eschatologische Neue gewesen ist, das wurde im Frühkatholozismus zum zu bewahrenden Alten. Die befreiende Autorität des Geistes wurde zur verpflichtenden Tradition” (Luz 1974:108). b. Die onderskeiding tussen ortodoksie en dwaalleer. Die dwaalleer word an die apostoliese $\pi \alpha \rho \alpha \theta \eta \dot{k} \eta$ gemeet, maar nie soos by Paulus teologies aan die kaak gestel nie maar sonder meer afgewys. c. Die verselfstandiging en beklemtoning van die etiek. Dit is naamlik opvallend watter sentrale plek paranese, onder andere die huistafels in die deutero-Pauliniese geskrifte, inneem in die geskrifte wat verteenwoordigend van vroegkatolisisme is. Dit moet na alle waarskynlikheid daaraan toegeskryf word dat wanneer geloof geword het tot 'n oorgelewerde leer, dit al moeiliker word om duidelik te maak in hoeverre so 'n soort geloof ook handeling, dit wil sê 'n lewe uit die geloof insluit. d. Die sekerstelling van die ware leer deur die sigbare ampskerk. Aan die bestaande kerklike ampte word nuwe funksies toegeken, waaronder veral die handhawing van die apostoliese tradisie en die bewaring van die leer. Hiërargiese strukture tree ook al meer na vore.

Benewens hierdie hoofkenmerke kan ook nog op die volgende met betrekking tot die vroegkatolieke geskrifte gewys word: die terugtree van 'n eie teologie; die neiging tot pseudonimiteit; die neiging om die geloof te objektiveer tot oordraagbare, vir eens en vir altyd vasgestelde formules; die neiging om die fides quae creditur bo die fides qua creditur te stel (kyk Luz 1974:107).

Die vraag wat onmiddellik na vore kom, is of aanvaar moet word dat hierdie ontwikkelings en veranderings onvermydelik was en dat dit nie as 'n afwyking gesien moet word van wat die toedrag van sake gedurende die apostoliese tyd was nie. Daar 
word dikwels rondom die vraag na die noodsaaklikheid al dan nie van kerklike geïnstitueerdheid verwys na die welbekende debat tussen Harnack wat van oordeel was dat kerkreg as eie aan die karakter van die kerk beskou moet word en Sohm wat geoordeel het dat dit strydig is met die wese van die kerk en dat die invoering daarvan gesien moet word as die sondeval van die kerk. In sy reaksie hierop het Bultmann (1968:447-452) geoordeel dat die meningsverskil toe te skryf is aan die verskillende persepsies oor die kerk wat Harnack en Sohm onderskeidelik daarop nagehou het en wat daartoe gelei het dat albei in hulle oordeel gefouteer het. Harnack het gefouteer deur die kerk te eensydig as 'n historiese en sosiologiese fenomeen te beskou en derhalwe te veel klem op die regsordelike geïnstitueerdheid van die kerk te lê. Sohm aan die ander kant, hoewel hy die selfverstaan van die vroegste kerk korrek beoordeel het, naamlik dat dit 'n eskatologiese fenomeen is wat deur die Gees gelei word, se fout het gelê "...in der Verkennung der Tatsache, daß eine regulierende Rechtsordnung nicht nur nicht im Gegensatz zum Walten des Geistes steht, sondern durch dieses auch gerade geschaffen werden kann” (Bultmann 1968:450).

Hoewel die debat tussen Harnack en Sohm klaarblyklik aan hulle uiteenlopende persepsies oor die kerk toegeskryf moet word, bly die vraag nog of die toenemende instituering van die kerk in die vroegkatolieke periode nie tog as 'n onvermydelikheid beskou moet word nie. Die vraag is dus of daardie na-apostoliese gemeenskappe in die lig van die uitbly van die paroesie anders kon as om een of ander kerklike organisasie met regs- of kerkordelike maatreëls op die been te bring. Sosiaal-wetenskaplike studies het aangetoon dat dit as 'n natuurlike ontwikkeling beskou kan word dat charisma tot 'n amp geroetineer word. In so 'n geval word die charisma gedissosieer van die individu wat die charisma sou ontvang het en word dit 'n bepaalde oordraagbare realiteit. En hoewel die essensie en uitoefening van die charisma deur roetinering ingrypend verander word, bly dit nog 'n baie belangrike element van die sosiale struktuur. So kan die proses van die transformasie van die charismatiese groep Jesusvolgelinge tot 'n kerk met 'n leer, 'n kultus en 'n kerklike organisasie beskryf word as 'n roetinering van charisma. Daar word ook op gewys dat charisma nie net as 'n slagoffer van roetinering gesien moet word nie, aangesien dit self aktief na institusionele manifestasie streef (kyk MacDonald 1988:1314). MacDonald toon verder oortuigend aan dat die proses van institusionalisering in die 
geval van Paulus en die deutero-Pauliniese briewe drie stadia deurloop het: eerstens dié van "community-building", die daarstelling deur Paulus van 'n simboliese universum vir die geloofsgemeenskap; tweedens dié van "community-stabilizing" by KolossenseEfesiërs, die transformering van die Pauliniese simboliese universum na nuwe situasies en die bewaring daarvan met die oog op die handhawing en sinvolle lewe van die gemeenskap; derdens dié van "community-protecting", die kerk as die draer en handhawer van die waarheid (regte leer) en die heftige verdediging van die gesag van die apostel teen dwaalleer (kyk veral MacDonald 1988:157-158).

Al sou dit ook blyk dat institusionalisering as onvermydelik beskou behoort te word, sal nog steeds uitgemaak moet word of die ontwikkelings wat plaasgevind het aan die "apostoliese" reg laat geskied het. Volgens Bultmann sal die basiese vraag wees “...ob und wieweit die entstehenden Ordnungen dem Wesen der Ekklesia als einer eschatologischen, durch das Wort der Verkündigung konstituierten Gemeinde angemessen waren und blieben" (1968:452). Hierby voeg hy ook nog die vraag of sodanige ordeninge van regulatiewe of van konstitutiewe aard was en watter instansie vir hulle daarstelling en handhawing verantwoordelik was, die gemeente of ' $n$ individu. Luz het nie twyfel oor wat die antwoord op bogenoemde vraag moet wees nie. Op sy vraag met betrekking tot die vroegkatolisisme: "Ist er also dem Apostolischen wirklich treu geblieben?", antwoord hy ondubbelsinnig: "Nein" (1974:108). Wat ironies is, is dat terwyl hierdie na-apostoliese geloofsgemeenskappe juis die apostoliese tradisies sogenaamd wou bewaar, beskerm en ongeskonde wou oorlewer, hulle juis nie daaraan laat reg geskied het nie. Maar nou moet hierby ook daarop gewys word dat dit nie so voor die hand liggend is wat onder "apostoliese" verstaan moet word nie. Dit skep die indruk dat daar 'n eenduidige apostoliese wyse van dink en doen was waaraan die latere ontwikkelings geëvalueer kan word, terwyl almal weet dat dit nie die geval was nie. Onder die inleiding hierbo is reeds daarop gewys dat daar nooit één oorspronklike model of persepsie van kerkwees, 'n Urgemeinde as 'n soort Urbild, bestaan het waaruit die ander ontwikkel het nie (kyk ook Roloff 1996:142; Von Lips 1996:67). En so min as wat dit vir die vroegste stadium gegeld het, so min het dit vir die sogenaamde apostoliese tyd gegeld. Dit is wel betreklik maklik om die deutero-Pauliniese ontwikkelings aan die 
hand van die Paulusbriewe te beoordeel, maar wat die res betref, is die saak nie so eenvoudig nie.

Dit sou ten slotte onbillik wees om bogenoemde ontwikkelings in hulle geheel negatief te evalueer en nie in aanmerking te neem dat hierdie geloofsgemeenskappe situasies van allerlei aard die hoof moes bied en daarop 'n antwoord moes gee nie. Wat ons wel as belangrik en noodsaaklik behoort te beskou, is om uit hierdie ontwikkelings in die vroegste kerkgeskiedenis lesse te leer wat die kerk nie in onaanvaarbare bane sal laat beweeg nie en indien gewens, die nodige koerswysigings sal laat maak. Die belangrikste lesse wat na my oordeel geleer behoort te word, is die volgende:

i. Watter waarde daar ook al aan tradisie en veral teologiese tradisie geheg behoort te word, mag dit nooit in die pad staan van voortgaande en vernuwende teologiese denke nie. Dan loop teologiebeoefening die gevaar om agter teologiese tradisie terug te tree. Teologiese tradisie mag ook nooit die evangelie wat as die enigste krag tot redding telkens nuut gehoor moet word, kondisioneer nie. Dit is wanneer teologiese tradisie(s) tot tradisiestuk(ke) versteen, dat woordverkondiging die gevaar loop om nie veel meer as die oorlewering van tradisiemateriaal of dogmas te wees nie, dat met "ortodoks" en "dwaalleer" as maatstokke geopereer word en dat nuwe stemme wat uit die teks gehoor word al te maklik tot dwaalleer verklaar word.

ii. Hoewel die kerk nooit sonder bedieninge kan wees nie, mag die kerk nie in so 'n mate 'n "amps"-kerk word dat dit nie meer deur die woordverkondiging nie, maar deur die ampte gekonstitueer word. Dit is dan wanneer die kerk nie meer deur die Gees gelei word nie en die ampte nie meer 'n regulerende nie maar 'n konstituerende karakter en funksie aanneem. Dit is ook dan wanneer die Gees nog slegs as amps-Gees figureer en nie meer as vrye gewer van gawes aan alle gelowiges gesien word nie. Soos ek in 'n vorige artikel (Pelser 1994:318) geoordeel het, moet die ampte funksioneer as funksies van en nie as dienslewering aan die liggaam van Christus nie. 
iii. Wanneer geloof tot leerstellige formules geobjektiveer en tot iets oordraagbaars word, kan dit maklik gebeur dat die vraag of 'n mens waarlik glo, tot op groot hoogte bepaal word deur hoe regsinnig jy is, dit wil sê hoe jy die kerk sy leerstellighede kan nasê. Dit is dan wanneer die fides qua creditur gevaar loop om agter die fides quae creditur terug te tree en die kerk nie meer 'n geloofsgemeenskap is nie maar 'n geloofsbelydenis-gemeenskap.

iv. Hierbo is die vermoede uitgespreek dat hoe meer geloof word tot die nasê en handhawing van oorgelewerde leerstukke, hoe moeiliker dit word om te verduidelik dat geloof ook handeling, 'n lewe uit die geloof moet insluit. Dit is dan wanneer etiek verselfstandig word, wanneer die imperatief los van die indikatief te staan kom en nie meer daarin gegrond is nie. Dit is dan wanneer die kerk se etiek maar net weer apodiktiese voorskrifte geword het en daar weinig oorgebly het van etiek as geloof wat deur die liefde tot dade oorgaan (Gal 5:6).

v. Hoewel die kerk nooit as gevolg van 'n gebrek aan orde mag mank gaan nie, mag kerklike geïnstitueerdheid ook nooit so 'n vorm aanneem dat dit tot 'n entiteit op sigself word en 'n gestruktureerdheid aanneem ten opsigte waarvan die "gewone" lidmaat 'n gevoel van vervreemding ervaar nie. Die kerk sal ook altyd daarteen moet waak dat dit nie 'n doel opsigself word nie, maar ook nie dat dit bloot 'n middel tot 'n doel word nie. Mense is nie in die eerste plek lid van die kerk nie en word nie deur die kerk gered nie, maar is lede van Christus en word deur Hom gered. 'n Mens kry te veel die indruk dat kerkwees geword het tot die formele: die deelhê van formele lidmate aan 'n noukeurig gestruktureerde onderneming waarin daar formeel gepreek word, mense in 'n formele, deur ampsdraers gestruktureerde erediens aanbid, formeel deelneem aan tientalle kerklike projekte waardeur nie alleen aanhoudend gepoog word om lidmate vir die kerk te werf en hulle as lidmate te behou nie, maar ook om hulle aan te spoor om steeds hulle verantwoordelikheid as lidmate op die talle kerklike en lewensterreine na te kom. Indien hierdie waarneming korrek is, verskil dit nogal aansienlik van die volgende 
stelling van Schweizer oor wat die Nuwe Testament onder andere van kerkwees verstaan:

Kult und Gottesdienst und Liturgie, die werden nach dem Neuen Testament vor allem auf den Bauplätzen und in den Kantinen, in den Büros und auf dem Acker draußen geleistet. Und die Priester, die diesen Kult zelebrieren, sind Kaufleute und Kellnerinnen, Krankenschwestern und Kapitäne der Industrie. Und die Tempel sind das Sitzungszimmer des Verwaltungsrates, wo in hartem Kampf für das Recht, gegen bloßen Profit gerungen wird, und das Bierlokal, wo ein Betrunkener sein Herz ausschütten kann.

(Schweizer 1970:243)

\section{WAT IS “KERK” VOLGENS DIE NUWE TESTAMENT?}

Uit die voorgaande het dit meer as duidelik geword dat daar Nuwe-Testamenties gesproke nóg 'n eenduidige nóg 'n eenstemmige antwoord op die vraag hierbo moontlik is. Hierdie situasie is in die eerste plek toe te skryf aan die hierbo genoemde onderskeid wat daar te bespeur is en getref behoort te word tussen onderskeidelik die "Jesus-woorde" en die "dood-en-opstanding-tradisie". Maar dan is dit ook toe te skryf aan die feit dat ongeag die tradisie wat deur ' $n$ bepaalde geloofsgemeenskap aangehang of gevolg is, daar ook binne hierdie onderskeie tradisiestrome 'n verskeidenheid van persepsies oor "kerkwees" geheers het, soos reeds verskeie kere deur ander uitgewys is en ekself in my reeds genoemde opstel probeer aantoon het (kyk weer Pelser 1995). In die lig hiervan sou geredeneer kon word dat dit nie legitiem of haalbaar is om van die "Nuwe Testament" se persepsie oor kerk-wees te praat nie, maar alleen van die onderskeie persepsies soos dit in die verskillende dokumente, verteenwoordigend van die verskillende geloofsgemeenskappe, na vore tree.

Hoewel so 'n afsonderlike ondersoek na die selfverstaan van elke vroegkerklike geloofsgemeenskap na my oordeel voorop behoort te staan, is dit inderdaad 'n vraag of dit vir kerklike selfverstaan in die huidige of toekomstige tydsgewrig voldoende sal wees. Natuurlik het dit in die verlede gebeur en sal dit ook in die toekoms gebeur dat die onderskeie grotere en kleinere strominge en denominasies in die Christendom in hulle 
kerklike selfverstaan en praktyk aan hierdie of daardie Nuwe-Testamentiese persepsie voorkeur gegee het en sal gee. Dit verklaar die kerlike verskeidenheid en selfs uiteenlopendheid wat daar in die Christendom te bespeur is. Hierdie toedrag van sake hoef egter nie te beteken dat 'n mens daarmee vir lief moet neem en nie mag en moet vra na wat uit die Nuwe Testament as gemeenskaplike vorme van kerklike selfverstaan vir die kerk vrugbaar gemaak kan word nie. Dit is dan ook opmerklik en betekenisvol dat terwyl die feit van die kerklike verskeidenheid in die Nuwe Testament vandag allerweë deur kritiese navorsers aanvaar word, dit blyk dat die meeste van hulle ook saamstem dat daar ' $n$ bepaalde eenheid te midde van die verskeidenheid aan te merk is (kyk Hultgren 1994:111), terwyl daar selfs dié is wat verkies om eerder van "Pluralität innerhalb einer Kohärenz" te praat (Schröter 2000:159).

Nou kan nie ontken word dat daar inderdaad 'n gemeenskaplikheid te midde van die verskeidenheid te bespeur is nie, ten spyte daarvan dat soos reeds hierbo betoog, die "Jesus-woorde-" en "dood-en-opstanding-tradisies" in die kern van die saak nie met mekaar te versoen is nie. Met ander woorde, die feit dat hulle tot op groot hoogte nie met mekaar te versoen is nie, beteken nie dat daar nie tog bepaalde gemeenskaplikhede te bespeur is nie. Soos gemerk kan word, verkies ek om van "gemeenskaplikheid" eerder as van "eenheid" te praat omdat laasgenoemde na my oordeel die indruk kan skep dat die onderskeie geloofsgemeenskappe doelbewus bepaalde kernelemente ter wille van 'n onderlinge eenheidsvisie probeer handhaaf het. Hierteenoor is ek van oordeel dat ons eerder te doen het met elemente wat uit allerlei oorde as erfstukke deel geword het van die onderskeie gemeenskappe se verstaan van kerk-wees. Intussen hoef ' $n$ mens egter nie hieroor hare te kloof nie en kan goedskiks na hierdie gemeenskaplikheid as eenheid verwys word.

Ek is my terdeë daarvan bewus dat wat hieronder as van die belangrikste en mees uitstaande "kenmerke" van kerk-wees onder die Nuwe-Testametiese geloofsgemeenskappe geïdentifiseer kan word nie, nie in gelyke mate van almal geld nie, en veral nie van die twee genoemde hooftradisiestrome nie. Hieruit moet verstaan word dat ek nie van mening is dat die verskille sonder meer oorbrug kan word of met mekaar geharmoniseer kan word nie. Tog meen ek dat die volgende in mindere of meerdere mate 
as die mees prominente kerlike kenmerke by die meeste van die geloofsgemeenskappe uitgesonder kan word:

a. Die kerk is 'n nuwe gemeenskap van mense wat deur 'n nuwe daad van God, die Jesusgebeure, in die geskiedenis tot stand gebring is om in verhouding met Hom te lewe, ongeag die onderskeie terme waarmee na hierdie gemeenskap verwys is

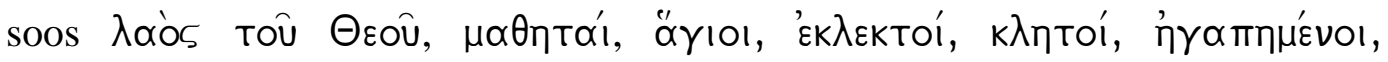

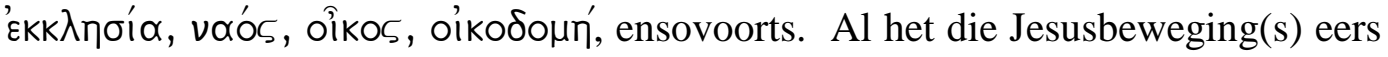
na 'n hele paar dekades as 'n selfstandige entiteit naas die Jodedom tot stand gekom, is daar klaarblyklik uit die staanspoor geglo dat God in Jesus iets nuuts tot stand gebring het.

b. Die kerk is 'n eskatologiese gemeenskap. Daar is meer as voldoende getuienis in die Nuwe Testament dat die onderskeie gemeenskappe vas daarvan oortuig was dat hierdie handeling van God nie alleen sy finale handeling met die mense was nie maar dat dit ook die huidige wêreldtyd tot 'n einde gebring het en dat die kerk daarom sy bestaan in "die laaste dae/tye" te voer het (kyk o a Hand 2:17; Heb 1:2; 1 Pet 1:20; Rom 13:12; 1 Kor 7:29; Gal 4:4) tot met die kulminering van alles by die wederkoms van Christus. Die feit dat daar betreklike meningsverskil is oor die vraag of die historiese Jesus se woorde of verkondiging deur 'n eskatologiese of miskien selfs ' $n$ apokaliptiese dimensie gekenmerk was, hoef nie te beteken dat sy vroegste volgelinge hulleself nie in 'n sekere sin as eskatologiese gemeenskap verstaan het nie. Wat hulle ook al verstaan het van Jesus se verkondiging en proklamering van die koningsheerskappy van God en die moontlikheid om daaraan deel te hê deur sy woorde hulle eie te maak, kon nie anders as om hulle daarvan te oortuig dat wie in die nuwe en onmiddellike verhouding met God te staan gekom het, deel geword het van 'n gemeenskap wat in meer as een opsig eskatologies genoem kan word nie. Hiermee word bedoel dat dit klaarblyklik vir hierdie vroegste gemeenskappe nie bloot gegaan het om die tydsdimensionele posisionering van die kerk nie, maar belangriker nog, om die kerk as vervulde entiteit, 'n $\pi \lambda \eta ́ p \omega \mu \alpha$, wat onafhanklik van die geskiedenis reeds is wat dit is en 
dit nie eers met verloop van die geskiedenis word nie. In hierdie sin is die bestaan van die kerk van paradoksale aard deurdat dit in die wêreldgeskiedenis bestaan, maar nie deel daarvan is nie, daaraan ontneem is. Tegelyk is die kerk as eskatologiese gemeenskap ook in dié sin 'n paradoksale entiteit dat dit in die wêreld kerk is, en nêrens anders nie, en tog nie van die wêreld is nie. Daar is meermale op gewys dat selfs toe daardie vroegste geloofsgemeenskappe met die uitbly van die paroesie besef het dat hulle hulle vir 'n onbepaalde tyd in die wêreld sal moet vestig, die gedagte dat die kerk in die einde van die tyd leef en nie 'n histories-wordende fenomeen is nie, nie laat vaar is nie. Die belangrike van hierdie aspek van kerkwees is vanselfsprekend dat die kerk dit as sy roeping moet sien om hier en nou en telkens weer voluit kerk te wees en nie daarop ingestel te wees om dit gaandeweg te word of met verloop van die geskiedenis beter of vollediger kerk te word nie. Dit is omdat die kerk nie in die geskiedenis word nie, dat gesê kan word dat die kerk 'n eskatologiese fenomeen is en daarom nie 'n geskiedenis het nie.

c. Die kerk is 'n heils-gemeenskap omdat dit bestaan uit mense wat hulleself ervaar as verlos van sonde en dood en as lewend vir God in verbondenheid met Jesus Christus (Rom 6:11). Vir Paulus is die evangelie sreng gesproke niks anders nie as die krag van God Eis ow Here Eis owtnpíav (Rom 10:10). Hiermee het Paulus verwoord wat op talle bladsye van die Nuwe Testament as die selfverstaan van die geloofsgemeen-

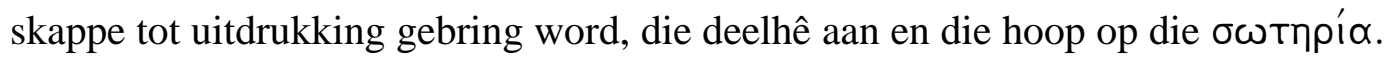
Hoewel teëgewerp kan word dat die tekste waarna hierbo verwys is, uit en uit die produk is van die "dood-en-opstanding-tradisie" wat ooreenkomstig my evaluering van hierdie tradisie nie geldigheid behoort te hê nie, moet daarop gewys word dat, sonder om na spesifieke uitsprake te moet verwys, 'n mens kwalik sou kon beweer dat die gemeenskap wat deur Jesus se woorde tot stand gekom het, hulle as iets anders as 'n heilsgemeenskap kon verstaan het. 
d. Die kerk is 'n kerugmatiese gemeenskap omdat dit deur die kerugma ontstaan het en bestaan. Die term kerugma word hier nie gebruik in die bykans tegniese sin waarvoor dit dikwels gebruik word met verwysing na die dood-en-opstandingtradisie soos dit by uitstek by Paulus voorkom nie. Dit het in dieselfde mate betrekking op die verkondiging van die heil deur die historiese Jesus as op die verkondiging van sy dood en opstanding as heilsgebeure. En of dit nou deur die verkondiging van die Jesus die "verkondiger" of Jesus die "verkondigde" is, dit is alleen in die kerugma dat ons God deur Jesus Christus ontmoet, nêrens anders nie, en dit is alleen deur die kerugma dat mense se lewens verander en vernuwe word, op geen ander wyse nie. Dit is om hierdie rede dat die verkondiging van die evangelie steeds as die belangrikste en sentraalste aktiwiteit van die kerk beskou moet word. Ek herinner my dat Bultmann êrens gesê het: "Die Kirche muss eine immer bessere Theologie fordern, aber nicht eine immer bessere Wortverkündigung, sondern nur Wortverkündigung überhaupt". Hiermee wou hy klaarblyklik sê, en 'n mens kan nie anders as om dit met hom eens te wees nie, dat die kerk sóveel erns met sy prediking moet maak en dat dit steeds van só 'n gehalte moet wees dat selfs die geringste gedagte om daarop te verbeter, nooit ter sprake mag wees nie. En soos die kerk deur die verkondiging tot stand kom, so begrond die bestaan van die kerk die verkondiging, want verkondiging geskied nie anders as deur die kerk nie, wat die samestelling en aard van 'n bepaalde geloofsgemeenskap ook al mag wees.

e. Die kerk is 'n geloofs-gemeenskap. Al sou 'n stelling soos hierdie ook al klink na die konstatering van die vanselfsprekende, kan nie genoeg beklemtoon word dat geloof die enigste gepaste antwoord op die kerugma is en daarom die enigste vereiste of kriterium vir lidmaatskap van die kerk nie. Dit is ook nodig om te beklemtoon dat hiermee die fides qua bedoel word, wat nooit verwar mag word met of verplaas mag word deur een of ander fides quae nie. Dit gaan hier dus nie om geloof in geloof nie, maar steeds om geloof in die evangelie waardeur God mense red. Dit is ook alleen as 'n fides qua dat geloof 'n lewende verhouding met God kan wees. Sogenaamde regsinnigheid word te dikwels gelyk gestel aan 
gelowig-wees of kerk-wees en so word geloof as kinderlike vertroue op God en as omhelsing van sy liefde en genade sy karakter en krag ontneem.

f. Die kerk is by uitstek 'n pneumatiese gemeenskap. Dit is opvallend watter prominensie in veral Handelinge, die Johannese geskrifte en die Paulusbriewe aan die Gees as gawe aan die geloofsgemeenskap gegee word. Hoewel dit wat die sinoptiese tradisie betref, nie in hierdie sin by Markus en Matteus figureer nie, het die prominente plek en funksie wat die Gees as gawe aan die geloofsgemeenskap by Lukas-Handelinge inneem, geen bewysvoering nodig nie. Veral by Paulus, hoewel natuurlik ook in Handelinge, word die Gees as gawe op die geloof voorgestel, en nie andersom nie, en word Hy voorgestel as dié teken dat die gelowige as eiendom van God beseël is of as waarborg dat God haar/hom as kind angeneem het. Daarom dat die Gees deur Paulus ook gewoon die Gees van kindskap genoem word. Paulus verleen soveel prominensie aan die Gees in die lewe van die gelowige dat hy in gelyke mate van Christus en die Gees in die gelowige praat (Rom 8:9) of van die gelowige in Christus of die Gees (Rom 8:9, 11; 1 Kor 3:16; 6:19). 'n Gelowige is iemand wat deur die Gees beheers word (Rom 8:14; Gal 5:18), wat deur die Gees lewe en wie se gedrag deur die Gees bepaal moet word (Gal 5:16, 25). Daarom kan Paulus ook van 'n gelowige

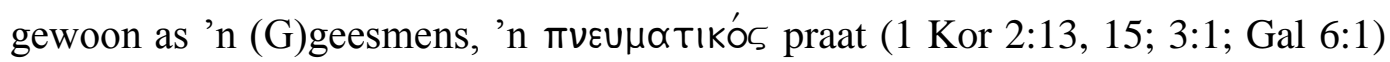

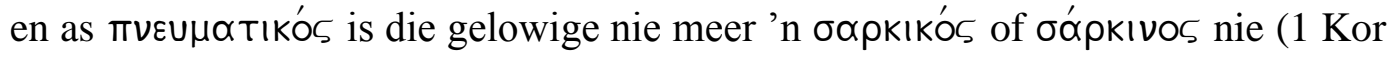
3:1, 3), nie meer iemand wat deur sy/haar aardse natuur beheers word nie. Uiteindelik kom dit daarop neer dat die kerk as pneumatiese gemeenskap bestaan uit mense wat deur die Gees herskep is tot radikaal nuwe mense.

g. Die kerk is 'n charismatiese gemeenskap, wat inhou dat dit nie alleen 'n gemeenskap is wat deur die inwoning en werk van die Gees tot nuwe mensheid herskep is nie, maar ook dat dit 'n gemeenskap is wat funksioneer deur middel van die verskeidenheid van gawes wat die Gees aan elkeen gee soos Hy wil (1 Kor 12:4-11). En hoewel die aanwesigheid van hierdie gawes op sigself hierdie gemeenskap as charismatiese gemeenskap kenmerk, is die Gees se 
oogmerk daarmee asmede die werklike toetssteen van charismatiese kerkwees die

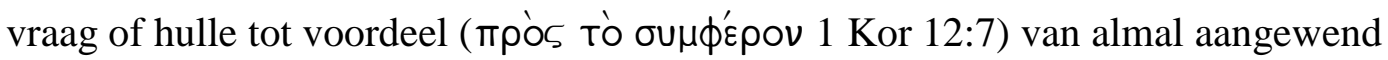
word. Die gawes word daarom eers sigbaar en as sodanig herkenbaar in die lewe van dié aan wie dit bedien word, dié tot wie se voordeel dit aangewend word. Hierby gaan dit nie om die begaafde nie, maar om die gawe, ongeag wie dit ontvang het. Die begaafde moet altyd agter die gawe terugtree. Sonder om die ou debat rondom charisma en amp te heropen, en te wil beweer dat Paulus wou dat die funksionering van die kerk volledig charismaties vry moet wees (kyk Von Lips 1996:66), moet daarop gewys word dat steeds daarteen gewaak moet word dat die gawe in die persoon van die ampsdraer opgaan en sodoende baie van sy betekenis en funksie verloor. In die Pauliniese gemeentes, hoewel dit klaarblyklik soms tot onordelikhede gelei het, was die klem beslis eerder op die vrye uitoefening van die charismata as op die inordening daarvan in 'n bepaalde struktuur, wat in elk geval nie bestaan het of deur Paulus gerade geag is nie.

h. Die kerk is 'n diakoniese gemeenskap. Roloff (1996:138) verwys met reg na die

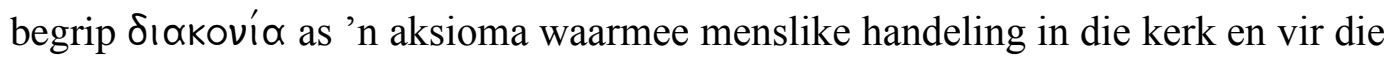
kerk verstaan en beskryf word. Volgens Markus 10:42-45 par, of die historiese Jesus inderdaad hier aan die woord was of nie, sou Jesus self sy volgelinge tot hierdie ingesteldheid opgeroep het. Dit is egter veral by Paulus dat die dienskarakter van gelowig-wees sterk op die voorgrond getree het en besondere beslag gekry het. Hy gebruik die term nie alleen met verwysing na sy eie werk nie (Rom 11:13; 2 Kor 5:18; kyk ook Rom 16:1), maar ook oorkoepelend of besonderlik na die verskeidenheid van funksies van die kerk as liggaam van Christus (1 Kor 12:5; 2 Kor 3:6; 4:1; 5:18; 8:4; 9:1; ens; vgl ook Hand 6:1, 4). Hier geld nie die mag van die sterkes nie, nie 'n hiërargiese struktuur nie, maar 'n helpende, van alle mag afsienende toewending van die lede van die gemeente na mekaar. Dit veronderstel tegelyk die afsien van status en die aanneem van 'n nederige houding wat in die vroegste Christendom die vooronderstelling geword het vir gesagsuitoefening binne die geloofsgemeenskap. Hierdie aksiomatiese oortuiging en praktyk het van hierdie gemeenskappe kontrasgemeenskappe 
gemaak wat hulle fundamenteel van die bestaande gemeenskappe onderskei het. “"Humility', elsewhere the disposition of slaves and dependants, becomes the characteristic of those who want to assume leadership roles in the community" (Theißen 1999:72). Dit is alleen as diakoniese gemeenskap dat die gawes van die Gees spontaan onderling beoefen kan word en nie vanuit 'n hiërargiese struktuur oor ander as 't ware uitgeoefen word nie. Daar is in die kerk 'n groot behoefte aan 'n ontspanne, spontane, nie oormatig gereglementeerde vorm van gelowigwees.

i. Die kerk is 'n koinonia-gemeenskap. Hoewel die werkwoord of substantief nie

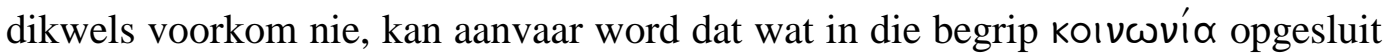
lê van grondliggende betekenis vir daardie vroegste geloofsgemeenskappe moet gewees het. Soos bekend, maak die outeur van Handelinge (2:42) daarvan een van die basiese karaktertrekke van die vroegste Jesusbeweging en dit was nie minder sterk by Paulus en klaarblyklik ook nie in die Johannese en Hebreërbrief se gemeenskappe aan die orde nie. Hierdie gemeenskaplikheidsgevoel en optrede teenoor mekaar het gespruit uit die gelowiges se deelhê aan Christus of die Gees, soos dit veral by Paulus en 1 Johannes na vore kom. Dit kan nie anders as omvattend wees en die hele spektrum van die lewe van die geloofsgemeenskap raak nie, anders is dit geen koinonia nie. Daar kan met reg gesê word dat dit deur al die eeue van die bestaan van die kerk as 'n sine qua non van kerkwees beskou is en dat dit nooit anders behoort te wees nie.

j. Ten slotte is die kerk 'n liefdes-gemeenskap. 'n Mens kan sonder vrees vir teenspraak sê dat daar nie 'n begrip in die Nuwe Testament is wat meer beskrywend van kerkwees is as die begrip liefde nie: die kerk bestaan uit gelowiges vir wie God liefhet en wat op God se liefde antwoord deur Hom en mekaar lief te hê. Wat buitengewoon is van hierdie liefde is dat dit grensloos is. Soos die liefde van God grensloos is deurdat dit ' $n$ liefde is vir magteloses, vir goddeloses, vir sondaars, vir vyande (Rom 5:6-10), so moet die liefde van die gelowiges ook grensloos wees. Dit moet nie net liefde vir die naaste, vir dié in eie 
kring wees nie, maar ook vir die vreemdeling (Luk 10:30-35) en selfs vir die vyand (Matt 5:44; Luk 6:27; vgl Rom 12:20). Dit is trouens volgens Paulus ook alleen deur die liefde dat geloof, soos dit hoort, 'n lewende geloof kan wees, tot dade oorgaan (Gal 5:6). En gelowiges mag ook niks anders aan mekaar verskuldig wees as om mekaar lief te hê nie (Rom 13:8).

\section{Literatuurverwysings}

Bultmann, R 1968. Theologie des Neuen Testaments. 6. Aufl. Tübingen: Mohr.

Conzelmann, H 1968. Grundriß der Theologie des Neuen Testaments. 2. Aufl. München: Kaiser.

Crossan, J D 1998. The birth of Christianity: Discovering what happened in the years immediately after the execution of Jesus. San Francisco: Harper.

Engelbrecht, J J 1995. Opmerkings oor vroeë katolisme in die Nuwe Testament, met besonder verwysing na die briewe aan die Kolossense en die Efesiërs, en die Pastorale Briewe. HTS 51(3), 677-701.

Funk, R W 1996. Honest to Jesus: Jesus for a new millennium. San Francisco: Harper.

Funk, R W and the Jesus Seminar 1998. The acts of Jesus: The search for the authentic deeds of Jesus. San Francisco: HarperCollins.

Grappe, C 2001. s v Kirche. $R G G$.

Hahn, F 1986. Das Problem des Frühkatholizismus, in Exegetische Beiträge zum ökumenischen Gespräch: Gesammelte Aufsätze, 39-56. Göttingen: Vandenhoeck.

Hultgren, A J 1994. The church in the New Testament: Polarities in discerning its identity. Dialog 33, 111-117.

Käsemann, E 1964. Einheit und Vielfalt in der neutestamentlichen Lehre von der Kirche, in Exegetische Versuche und Besinnungen II, 262-267. Göttingen: Vandenhoeck.

Kirchschläger, W 1990. Die Anfänge der Kirche: Eine biblische Rückbesinnung. Graz: Verlag Styria.

Kloppenberg, J A 1987. The formation of Q: Trajectories in ancient wisdom collections. Philadelphia: Fortress.

Koester, H 1990. Ancient Christian gospels: Their history and development. London: SCM. 
Küng, H 1970. Der Frühkatholizismus im Neuen Testament als kontroverstheologisches Problem, in Käsemann, E (Hrsg), Das Neue Testament als Kanon, 175-204. Göttingen: Vandenhoeck.

Luz, U 1974. Erwägungen zur Entstehung des "Frühkatholizismus": Eine Skizze. ZNW $65(1 \& 2), 88-111$.

MacDonald, M Y 1988. The Pauline churches: A socio-historical study of institutionalization in the Pauline and Deutero-Pauline writings. Cambridge: Cambridge University Press.

Mack, B L 1995. Who wrote the New Testament?: The making of the Christian Myth. San Francisco: HarperCollins.

Pelser, G M M 1990. Die bedieninge in die Nuwe Testament: 'n Ondersoek na historiese wording en prinsipiële regverdigbaarheid. Praktiese Teologie in Suid-Afrika 5, $1-18$.

Pelser, G M M 1994. Enkele opmerkings oor die wese van die kerk. HTS 50(1\&2), 311329.

Pelser, G M M 1995. Die kerk in die Nuwe Testament. HTS 51(3), 645-676.

Roloff, J 1978. s v Amt, Ämter, Amtverständnis. TRE.

Roloff, J 1993. Die kirche im Neuen Testament. Göttingen: Vandenhoeck. (GNT 10.)

Roloff, J 1996. Kirchenleitung nach dem Neuen Testament: Theorie und Realitiät. KuD 42(2), 136-153.

Schmithals, W 1994. Theologiegeschichte des Urchristentums: Eine problemgeschichtliche Darstellung. Stuttgart: Kohlhammer.

Schröter, J 2000. Jerusalem und Galiläa: Überlegungen zur Verhältnisbestimmung von Pluralität und Kohärenz für die Konstruktion einer Geschichte des frühen Christentums. NT 42(1), 127-159.

Schulz, S 1976. Die Mitte der Schrift: Der Frühkatholizismus im Neuen Testament als Herausforderung an den Protestantismus. Stuttgart: Kreuz.

Schweizer, E 1962. Erniedrigung und Erhöhung bei Jesus und seine Nachfolgern. 2. stark umgearbeitete Aufl. Zürich: Zwingli Verlag. (Abhandl z Theol des A u N T 28.) 
Schweizer, E 1970. Die Kirche, in Beiträge zur Theologie des Neuen Testaments, 237247. Zürich: Zwingli Verlag.

Theißen, G \& Merz, A 1997. Die historische Jesus: Ein Lehrbuch. 2, durchgesehene Aufl. Göttingen: Vandenhoeck.

Theißen, G 1999. The religion of the earliest churches: Creating a symbolic world. Translated by John Bowden. Minneapolis: Fortress.

Trilling, W 1988. Implizite Ekklesiologie: Ein Vorschlag zum Thema Jesus und die Kirche, in Studien zur Jesusüberlieferung, 165-183. Stuttgart: Verlag Katholisches Bibelwerk. (Stuttgarter Biblische Aufsatzbände, Neues Testament 1.)

Von Lips, H 1996. Neutestamentliche Aspekte zur Ekklesiologie. BThZ 13(1), 60-70. 